\title{
Anesthesia Medications and Interaction with Chemotherapeutic Agents
}

Jeremy Watson · Michael K. Ninh · Scott Ashford · Elyse M. Cornett •

Alan David Kaye · Ivan Urits · Omar Viswanath

Received: January 7, 2021 / Accepted: March 13, 2021 / Published online: April 16, 2021

(C) The Author(s) 2021

\section{ABSTRACT}

Cancer is now a leading health concern worldwide. In an effort to provide these patients with adequate care, coordination between anesthesiologists and surgeons is crucial. In cancer-related treatment, it is very clear that radiochemotherapy and medical procedures are important. There are some obstacles to anesthesia when dealing with cancer treatment, such as physiological disturbances, tumor-

J. Watson - M. K. Ninh $\cdot$ S. Ashford

LSU Health Shreveport, 1501 Kings Hwy,

Shreveport, LA 71103, USAJ. Watson

e-mail: jwats9@lsuhsc.eduM. K. Ninh

e-mail: mninh@lsuhsc.eduS. Ashford

e-mail: sashfo@lsuhsc.edu

\section{E. M. Cornett ( $\square)$}

Department of Anesthesiology, LSU Health

Shreveport, 1501 Kings Highway, P.O. Box 33932,

Shreveport, LA 71103, USA

e-mail: ecorne@lsuhsc.edu

\section{A. D. Kaye}

Departments of Anesthesiology and Pharmacology,

Toxicology, and Neurosciences, LSU Health

Shreveport, 1501 Kings Highway, Shreveport, LA

71103, USA

e-mail: akaye@lsuhsc.edu

I. Urits

Department of Anesthesia, Critical Care, and Pain

Medicine, Beth Israel Deaconess Medical Center,

330 Brookline Ave, Boston, MA 02215, USA

e-mail: iurits@bidmc.harvard.edu related symptoms, and toxicity in traditional chemotherapy treatment. Therefore, it is important that a multisystemic, multidisciplinary and patient-centered approach is used to preserve perioperative homeostasis and immune function integrity. Adding adjuvants can help increase patient safety and satisfaction and improve clinical efficacy. Correctly paired anesthetic procedures and medications will reduce perioperative inflammatory and immune changes that could potentially contribute to improved results for future cancer

O. Viswanath

Department of Anesthesiology, Louisiana State

University Shreveport, Shreveport, LA, USA

O. Viswanath

Valley Pain Consultants - Envision Physician

Services, Phoenix, AZ, USA

O. Viswanath

Department of Anesthesiology, University of

Arizona College of Medicine-Phoenix, Phoenix, AZ, USA

O. Viswanath

Department of Anesthesiology, Creighton

University School of Medicine, Omaha, NE, USA 
patients. Further research into best practice strategies is required which will help to enhance the acute and long-term effects of cancer care in clinical practice.

Keywords: Anesthesia; Cancer; Desflurane; Isoflurane; Ketamine; Oncology; Pain; Propofol; Sevoflurane

\section{Key Summary Points}

A multisystemic, multidisciplinary and patient-centered approach is crucial to preserve perioperative homeostasis and immune function integrity in cancer patients.

Adding adjuvant treatments can increase patient safety and satisfaction and improve clinical efficacy.

Correctly paired anesthetic medications and procedures will reduce perioperative inflammation that could potentially contribute to improved results for cancer patients.

More research involving multidisciplinary treatment and adjuvant therapy is required to help enhance the acute and long-term effects of cancer care in clinical practice.

\section{DIGITAL FEATURES}

This article is published with digital features, including a summary slide, to facilitate understanding of the article. To view digital features for this article, go to https://doi.org/10.6084/ m9.figshare.14207312.

\section{INTRODUCTION}

The interactions between oncology and anesthesiology have become a significant concern over the past three decades. According to a global health study of 29 cancer groups from 2006 to 2016, cancer incidence has increased by $28 \%$ [1]. Also, the majority of patients with cancer require some form of anesthesia for firstline surgical treatments such as mastectomy, lobectomy, colon resection, gastrectomy, and bladder resection, among other procedures. Clinical trials of anesthetic interactions are minimal due to a combination of drug regimens for appropriate surgical sedation. Laboratory and animal studies, however, suggest an association between anesthetic drugs and cancer cell proliferation and inhibition.

For example, halothane, ketamine, and thiopental have been shown to inhibit natural killer cell (NK) activity, which is essential for tumor cell detection and elimination [2, 3]. There is also evidence that opioids suppress the immune system, although the mechanism is not understood [4]. Volatile agents such as isoflurane, sevoflurane, and halothane have also been studied in the setting of cancer metastasis through T-lymphocyte apoptosis and upregulation of hypoxia-inducible factor 1-alpha (HIF$1 \alpha)$ and, consequently, vascular endothelial growth factor (VEGF) [5-8]. Propofol, a commonly used sedative-hypnotic agent, can downregulate HIF- $1 \alpha$ and inhibit cell migration through neuroepithelial cell transforming gene1 and promote cell apoptosis through the miR24/p27 pathway [9-12]. Propofol can upregulate the expression of the inhibitor of growth 3 (ING3) gene. ING3 is a member of the ING tumor-suppressor family known to modulate transcription and apoptosis through histone acetylation of p53 [13, 14]. Furthermore, ING3 is involved in the progression of head and neck squamous cell carcinoma, colorectal adenoma, hepatocellular carcinoma, and gastric cancer, thereby suggesting propofol use in the oncological setting $[13,15,16]$.

Furthermore, concomitant administration of halothane and cyclophosphamide have been associated with increased toxicity and mortality in both animal and clinical studies [17, 18]. Lidocaine specifically inhibits bleomycin degradation and repair of bleomycin-induced DNA breakage [17, 19] Cardiotoxicity from anthracyclines and monoclonal antibodies such 
as trastuzumab can cause fatal arrhythmias if QT-prolonging drugs such as propofol or beta-2 agonists are administered [20]. This paper will review the current literature discussing the interaction between anesthetic agents, cancer, and chemotherapy agents. Further clinical outcome studies are warranted for the use of specific anesthetic drugs in the reduction of cancer recurrence. This article is based on previously conducted studies and does not contain any new studies with human participants or animals performed by any of the authors.

\section{Effect of Anesthesia on Immunosuppression}

Ketamine, thiopental, propofol, opioids, and volatile agents have been well studied in immunosuppression. Ketamine acts on the mitochondrial pathway and induces lymphocyte apoptosis in human cells [21]. Specifically in breast cancer cells, however, bcl-2 is upregulated and causes cancer proliferation and invasion [22]. Ketamine also reduces the expression of CD40, CD80, and major histocompatibility complex (MHC) class II molecules in dendritic cells, decreasing interleukin (IL)- 6 and tumor necrosis factor alpha (TNF- $\alpha$ ), and thereby reducing the cell-mediated response [23]. In contrast, thiopental is shown to minimize activation of nuclear factor kappa $\mathrm{B}(\mathrm{NF}-\kappa \mathrm{B})$ and decrease expression of IL-2, IL-6, IL-8, and interferon gamma (IFN- $\gamma$ ) [24]. Although the mechanisms of these drugs are different, studies show an increase in lung and liver metastasis with both ketamine and thiopental use.

Several studies suggest that the role of propofol in antitumor immunity is through its antioxidant and anti-inflammatory effects. Propofol inhibits cyclooxygenase (COX) activity, decreases IL-8 levels, and increases cytotoxic T-lymphocyte activity and IL-10 production [25-27]. In non-small cell lung cancer (NSCLC), propofol inhibits HIF- $1 \alpha$ through the reduction of lipopolysaccharide-induced nuclear accumulation [11]. Additionally, propofol does not alter NK activity or Th1/Th2, IL-2/IL-4, and CD4/ CD8 T-cell ratios, suggesting its use in various oncological procedures [28]. Opiates and their derivatives act directly through opioid receptors and toll-like receptors and indirectly through the hypothalamic-pituitary-adrenal (HPA) axis as well as the sympathetic nervous system (SNS). By binding to the mu-opioid receptor, T-cell differentiation is decreased through the reduction of IL-1, IL- 6 , and TNF- $\alpha$. The activation of the HPA axis and SNS causes an upregulation of immunosuppressive cytokines such as IL-4, IL-10, and transforming growth factor beta (TGF- $\beta$ ), and can promote cancer proliferation and metastasis [3, 29]. Interestingly, methylnaltrexone has been studied in the setting of decreasing cancer proliferation and metastasis, particularly in NSCLC [30, 31]. Additional studies support morphine use in reducing angiogenesis, invasion through matrix metalloproteinases (MMP), and metastasis for breast cancer [32-34]. Further studies are warranted before new opioid protocols can be implemented.

The results regarding the effects of volatile anesthetics on immunosuppression are mixed, likely due to varying effects on different cancer types and studies. In general, volatile agents such as halothane, sevoflurane, desflurane, and isoflurane can decrease $\mathrm{NK}$ cell activity and have variable effects on HIF- $1 \alpha[3,35]$. Interestingly, sevoflurane can suppress HIF- $1 \alpha$ in lung cancer cells through the p38 mitogen-activated protein kinase (MAPK), whereas HIF- $1 \alpha$ is upregulated in head and neck squamous cell carcinoma. Sevoflurane reduces the risk of metastasis for both cancer types through this pathway [36, 37]. In contrast, isoflurane has been shown to increase the malignant potential of ovarian cancer cells through upregulation of insulin-like growth factor 1 (IGF-1) and VEGF, likely through HIF-1 $\alpha$ expression [38]. Both sevoflurane and isoflurane induce lymphocyte apoptosis, whereas halothane and desflurane do not $[3,39]$. The effects of anesthetic drugs on immunosuppression vary widely and will need to be further studied in the context of both normal tissue and cancer. 


\section{Timing of Surgery}

There are three classifications of chemotherapy in the setting of surgery: neoadjuvant, adjuvant, and palliative therapy. Neoadjuvant therapy is treatment before surgery, where the focus is specifically aimed at shrinking the tumor, destroying malignant cells, and reducing the complexity of the procedure. Adjuvant therapy is given after surgery with the goal of reducing cancer recurrence [40]. Palliative therapy is given to improve quality of life and prolong survival when no cure is possible [40]. Pathological complete response (pCR) is a term that refers to the elimination of invasive cancer in a tissue sample after resection of the tumor. Various types of cancers and their optimal timing for surgery have been investigated with respect to the risk of cancer growth. In a retrospective study of 7794 patients with stage II and III colon cancer, an increased risk of mortality was found in patients initiating adjuvant therapy more than 44 days after surgery. Each week of delay was associated with a $7 \%$ decrease in survival, highlighting the importance of receiving chemotherapy within 6 weeks after surgical resection [41].

For timing between neoadjuvant therapy and lobectomy in clinical stage IIIA NSCLC, findings suggest that overall survival is significantly lower in patients who undergo surgery after 6 weeks. Studies suggest that timing between neoadjuvant therapy and surgery has no impact on long-term outcomes and survival for gastric and esophageal cancers [42, 43]. In a meta-analysis of adjuvant chemotherapy, delaying treatment more than 6 weeks was associated with decreased overall survival for both colorectal and gastric cancer (hazard ratio $=1.2$ ). The timing of adjuvant therapy after pancreatic cancer did not affect long-term outcomes [44]. These studies discourage a delay in both surgery and adjuvant therapy in cancer patients.

The time interval between chemotherapy and breast surgery has been debated. Many patients in clinical settings decide on breast conservation therapies and would delay treatment based on the severity of the disease and the various treatment options available. The ideal time for optimal survival from diagnosis is less than 90 days for surgery, less than 120 days for chemotherapy, and less than 1 year for radiotherapy [45]. In a study evaluating pCR, overall survival, and disease-free survival in 611 patients diagnosed with stage II and III breast cancer, the optimal timing of surgery was reportedly between 4 and 7 weeks [46]. In a study that included stage I-III breast cancer, adverse outcomes were associated with delaying adjuvant chemotherapy more than 91 days after breast surgery [47]. Although the specific time frame between chemotherapy and surgery differs based on the inclusion criteria for these studies, it can be inferred that delaying surgery more than 6 weeks post-neoadjuvant therapy is associated with cancer growth and invasion. Similarly, patients should be started on adjuvant therapy within 6 weeks after surgery for optimal outcomes and survival. These guidelines are helpful when assessing patients in the preoperative setting because of potential interactions between anesthetic drugs and chemotherapeutic agents.

\section{General Anesthesia}

Inhaled anesthetic agents include enflurane, desflurane, halothane, isoflurane, sevoflurane, and nitrous oxide $\left(\mathrm{N}_{2} \mathrm{O}\right)$. The exact mechanism of action of these agents is unknown but is believed to inhibit excitatory synaptic pathways and amplify inhibitory postsynaptic channel activity within the central nervous system. The amount of each inhaled anesthetic agent that must be administered to provide anesthesia is termed the minimum alveolar concentration (MAC). Some studies have investigated the interaction between the inhaled anesthetic agents and chemotherapeutic agents that alter MAC. In a survey of patients with hepatocellular carcinoma, neoadjuvant chemotherapy with oxaliplatin and tegafur reduced the MAC values of sevoflurane and desflurane [48]. The MAC required to block autonomic response (MACBAR) was lower with sevoflurane combined with neoadjuvant chemotherapy using oxaliplatin and Gio in gastric cancer patients [49]. These findings suggest a titration of the anesthetic 
dose based on the interaction with the corresponding chemotherapeutic agent. Other studies have found that specific chemotherapeutic agents perform better when administered in conjunction with inhaled anesthetics than when administered alone. In a study on human lung adenocarcinoma, cisplatin exhibited more significant cell growth suppression when administered with sevoflurane than when administered alone [50]. Another study found that halothane enhanced the antitumor effect of IFN- $\gamma$ when the two were combined in human colon cancer cells compared to nonhalothane treatment [51]. Some studies have shown that certain anesthetics and chemotherapeutic agents interact differently depending on the type of cancer. Sevoflurane and cisplatin produce chemoresistance in renal cell carcinoma cells, and cause increased chemosensitivity in non-small cell lung cancer cells [52]. It was also found that exposure to inhaled anesthetics and neoadjuvant chemotherapy promoted cancer progression. Isoflurane upregulates HIF- $1 \alpha$ and its downstream effects in prostate cancer cells and the development of chemoresistance [6]. In another study showing cancer progression, sevoflurane was used in an in vitro model of estrogen receptor-positive (ER+) and ER- breast cancer. In the ER+ breast cancer cells, proliferation, invasion, and migration were increased. An increase in migration and proliferation, but not invasion, was also observed in the ER- breast cancer cells [53]. These studies show the importance of knowing the type of cancer, and if possible, the genetic factors of cancer before deciding which inhaled anesthetic is ideal for the treatment of each patient.

\section{Agents}

Two intravenous (IV) anesthetic agents that interact with chemotherapeutic drugs are propofol and ketamine. Propofol works by amplifying the GABA-mediated inhibitory tone within the central nervous system to provide its anesthetic effect. Ketamine is an NMDA receptor antagonist that creates a dissociative anesthetic effect. Propofol has been thoroughly investigated due to its ability to enhance the efficacy of chemotherapeutic agents when used in conjunction. Propofol and BCR-ABL tyrosine kinase inhibitors (TKIs) were studied in both in vitro and in vivo xenograft models to explore a potential synergistic benefit when used in combination for the treatment of chronic myeloid leukemia (CML). Propofol and dasatinib administration led to lower CML CD34 cells. Also, propofol and imatinib led to lower levels of p-Akt, p-mTOR, and p-S6. This study suggests that propofol use in conjunction with BCR-ABL TKIs led to an enhanced inhibitory effect shown by increased suppression of the Akt/mTOR pathway [54]. In a cervical cancer study, propofol was able to enhance cisplatininduced cell apoptosis via the EGFR/JAK2/ STAT3 pathway [55]. An ovarian cancer cell study found that propofol induced apoptosis of the ovarian cancer cells and enhanced the paclitaxel killing capacity of paclitaxel-sensitive and paclitaxel-resistant cancer cells. The paclitaxel-resistant cancer cells were shown to express high levels of transcription factor Slug, which correlated with increased chemoresistance. Propofol administration led to significantly lower Slug levels and therefore increased the chemosensitivity of the ovarian cancer cells [56]. A study on a pancreatic cancer cell line MIA PaCa-2 treated with gemcitabine showed that propofol could downregulate nuclear factor- $\kappa \mathrm{B}$, leading to the chemosensitization of these pancreatic tumors to gemcitabine [57]. Though numerous studies highlight propofol's ability to enhance the efficacy of chemotherapeutic agents, studies have also shown deleterious effects of propofol on chemotherapeutic agents. It was found that propofol reduced the cytotoxicity of cisplatin through the inhibition of gap junction intercellular communication, which resulted in decreased cytotoxicity [58]. Ketamine administration alone has been shown to be extremely advantageous in treating cancers and is known to have an inhibitory effect on many different forms of cancer. In a study on gastric cancer, it was found that ketamine inhibited the progression of gastric cancer via apoptosis and attenuation of the PI3K/Akt/ mTOR pathway [59]. Another study found that pancreatic cancer cells expressed an NMDA 
receptor which, when exposed to ketamine, decreased the rate of proliferation and apoptosis and increased necrosis in human adenocarcinoma pancreatic cells [60]. In lung adenocarcinoma, an NK cell activation marker, CD69, was found to be downregulated. Ketamine administration induced apoptosis in lung adenocarcinoma through the upregulation of CD69 [61].

\section{Regional Anesthesia}

Regional anesthetics block voltage-gated sodium channels, which then prevents sodium from entering the cell, in turn blocking impulse transmission. Regional anesthetic groups are categorized based on where their metabolism occurs. The amino-amides such as bupivacaine, ropivacaine, and lidocaine are hydrolyzed in the liver, whereas plasma cholinesterases metabolize the amino-esters such as procaine, chloroprocaine, and tetracaine [62]. Many of the regional anesthetics have antitumor effects when administered alone, but also increase the efficacy of chemotherapeutic agents when administered together. One study investigated orthotic transplantation of bladder cancer cells into rats and found that mitomycin $\mathrm{C}$ alone was not effective for treatment. However, the use of lidocaine and mitomycin $\mathrm{C}$ was found to prolong survival and reduce wet bladder weight [63]. A study performed on human breast cancer cell lines MCF-7 and MDA-MB-231, which are triple-negative breast cancer cell lines, showed that lidocaine increased the sensitizing effects of cisplatin. When cisplatin was combined with lidocaine, an increased apoptosis ratio and enhanced inhibitory effect of cisplatin was found [64]. A study with gastric cancer cells found that with administration of bupivacaine, their migration was inhibited at low $(0.1 \mathrm{mM}$ and $0.05 \mathrm{mM})$ and high doses $(1 \mathrm{mM}$ and $5 \mathrm{mM}$ ); however, only high doses were found to inhibit the survival of the cancer cells. When bupivacaine was then administered with 5-fluorouracil (5-FU), a significant enhancement in the inhibition of cancer cell growth and survival, but not migration, was observed [65]. In melanoma cells, ropivacaine and lidocaine increased the in vitro efficacy of dacarbazine on the inhibition of migration, inhibition of proliferation, and increased apoptosis in melanoma cells. When either ropivacaine or lidocaine was used in the treatment of melanoma cells with vemurafenib, it was found to be more effective than vemurafenib alone in the treatment of melanoma [66]. Some studies have investigated the use of lidocaine for overcoming chemotherapeutic resistance in specific cancers. A study conducted on the cisplatin resistance of A549/DDP cells found that lidocaine provided inhibition of cell viability, cell migration, and cell invasion and reduced cisplatin resistance. The cisplatin resistance was due to high expression of miR-21in A549/DDP cells, and miR-21 expression was found to be decreased after lidocaine administration. The study then administered an miR-21 inhibitor, which was found to have the same decreasing cisplatin resistance effect as lidocaine. This showed that lidocaine re-sensitized cisplatin to A549/DDP cells via decreased expression of miR-21 [67]. Another study investigated the use of lidocaine in regulating $A B C$ transporter proteins, which are implicated in chemotherapeutic resistance. This study was conducted on choriocarcinoma JEG-3 and JAR cells and the administration of lidocaine and 5-FU. The study found that lidocaine in low concentrations had no effect but, when administered at high doses, stimulated cell apoptosis. When lidocaine was administered in conjunction with 5-FU, JEG-3 and JAR cell line sensitivity to 5 -FU was enhanced via increased induction of apoptosis. This study found that lidocaine enhanced the cytotoxic effect of 5-FU to choriocarcinoma cells by reducing resistance via the downregulation of $\mathrm{ABC}$ transporter protein expression [68].

\section{Adjuvant Drugs}

\section{Opioids}

Opioids are potent analgesics and have been widely used in the perioperative setting for surgery. Opioids are most commonly utilized in peripheral and neuraxial anesthesia. Their use is still limited because of the side effects that accompany their use, such as respiratory breathing, nausea, clouding of consciousness, 
constipation, addiction, and tolerance [69]. The opioids exert their effects by potentiating the anti-nociception of local anesthetics via $G$ protein-coupled receptor mechanisms, resulting in afferent sensory neuron hyperpolarization [70]. Adjuvant use of buprenorphine in the setting of regional anesthesia is one example of studies showing the median duration of analgesia for upper and lower nerve blocks. By blocking the inward rectifying potassium channels, the cells become hyperpolarized, resulting in continued neuronal excitability inhibition. The use of morphine intrathecally has been shown to prolong postoperative analgesia when combined with intrathecal bupivacaine or ropivacaine. Opioids, in conjunction with local anesthetics, produce a much greater analgesic effect than either medication used alone. The combination of these agents also lowers the risk of experiencing side effects. The cytotoxic effects of chemotherapy are reduced with the concurrent use of opioids. This effect has been observed with the administration of cisplatin. Tramadol and flurbiprofen have been shown to interfere with cisplatin cytotoxicity through their effect on the coupling of gap junctions [71]. The decrease in gap junction coupling results in a decrease in the cytotoxicity of cisplatin [72].

There is evidence of immune suppression with opioids. Human cell and animal cell studies show that the administration of morphine and other opioids in acute and chronic conditions results in a reduction of cell immunity [73-76]. The immunomodulatory effects of morphine are present in preclinical and clinical studies [76]. Furthermore, morphine is associated with faster cancer development and increased vulnerability to infection. Finally, in vivo animal and in vitro human studies show that intravenous opioids decrease NK cell cytotoxicity (NKCC) [77, 78]. The exact impact of opioid-mediated immunosuppression depends on the agent. Although morphine-, codeine-, and fentanyl-mediated immunosuppressive effects in animal models have been substantiated, partial agonist buprenorphine tends to have a more favorable immune profile devoid of intrinsic immunosuppressive activity [78].
Fentanyl transdermal patch is approved for use in patients with chronic pain who receive at least $60 \mathrm{mg}$ oral morphine or equivalent daily or require continuous dosing. Transmucosal immediate-release fentanyl (TIRF) is approved for breakthrough cancer pain in opioid-tolerant patients who also require at least $60 \mathrm{mg}$ of oral morphine or equivalent daily. Many drugs used to treat cancer are metabolized by the cytochrome P450 (CYP450) system. Fentanyl is a weak substrate of CYP2D6, CYP3A4, and P-glycoprotein, and concurrent use of fentanyl and a kinase inhibitor such as imatinib (a CYP3A4 inhibitor) or nilotinib (CYP3A4 and P-glycoprotein inhibitor) can increase sedation in patients [79].

\section{Lidocaine}

Local anesthetics are known for their ability to block $\mathrm{Na}+$ channels. Aside from where they are used traditionally, they have significant effects in multiple settings other than local and regional anesthesia or antiarrhythmic treatment. Direct administration of lidocaine during tumor resection resulted in a substantial reduction in pulmonary metastasis. Still, this effect was only observed when combined with sevoflurane and not with ketamine, suggesting that the therapeutic value of lidocaine is dependent on the combination of anesthetics used during the perioperative administration of voltage-gated sodium channel inhibitors [80]. In a similar model, the perioperative administration of lidocaine in conjunction with sevoflurane resulted in a reduction in pulmonary metastases [81]. These nontraditional effects result from the ability of local anesthetics to interact with other cellular systems. Lidocaine has been shown to cause sensitization of tumors against chemotherapeutic agents, and this phenomenon was linked to lidocaine's ability to enhance the effectiveness of the chemotherapeutic agent through lidocaine-induced demethylation of deoxyribonucleic acid in breast cancer cells, thus interfering with the regulation of gene expression within the tumor [82]. A murine model of breast cancer surgery, which used sevoflurane as its general anesthetic, showed that the administration of lidocaine with intravenous cisplatin significantly 
decreased lung metastatic colony counts when compared to intravenous administration of cisplatin alone, which is correlative with perioperative lidocaine attenuating the metastatic activity after cancer surgery [83]. A similar study investigating hepatocellular carcinoma showed that lidocaine both suppressed tumor development and enhanced tumor cell sensitivity to cisplatin [84]. The accumulation of in vitro and in vivo preclinical evidence suggests that repurposing lidocaine to the oncology setting may be of therapeutic value and is now being investigated for potential associations with cancer outcomes. However, these studies have shown results that contradict one another. Overall, there is an abundance of substantial evidence suggesting a therapeutic role in the perioperative setting. Carefully planned clinical trials are needed to effectively test the antitumor effects of general anesthetics, such as lidocaine.

\section{Nonsteroidal anti-inflammatory drugs (NSAIDs)}

Many types of cancers express cyclooxygenase-2 (COX-2), which plays a very important role in the promotion of carcinogenesis and cancer cell resistance to chemo- and radiotherapy. Cancer cell resistance to chemotherapeutic drugs is closely associated with COX-2 interactions with transcriptional regulator proteins and antiapoptotic mediators. Thus, COX-2 inhibition is a probable mechanism of exerting therapeutic effects such as reducing metastatic spread in cancer patients. However, COX-2 is known to be adversely induced by chemotherapeutic agents. Compared with standard cancer therapies, COX-2 inhibitors such as NSAIDS are relatively inexpensive, have tolerable side effects, and can also sensitize cancer cells to radio- and chemotherapy treatment regimens [85]. Studies have shown a positive correlation between COX-2 expression and the resistance of head and neck squamous cell carcinoma (HNSCC) to anticancer drugs, and COX-2 inhibition was found to play an important role in increasing the chemoresponse of tumor cells [86, 87]. One study demonstrated that celecoxib has a potent anticancer effect on HNSCC cells and that its receptor-independent increase in reactive oxygen species (ROS) mediates its effect on cancer cell death [88]. COX-2 inhibitors are able to relieve COX-2 mediated expression of multidrug resistance proteins [89], and when administered in a perioperative setting, the inhibitors were shown to reduce the risk of surgical-related metastasis [90, 91]. An increase in patient survival and a reduction in cancer recurrence has been demonstrated through the use of NSAIDS. The combination of NSAIDS with chemotherapeutic agents has been reported to synergistically increase the antitumor activity of certain chemotherapeutic agents as well as improve the rate of tolerance to chemoradiation and the overall response rate for cancer at advanced stages. This is especially true when NSAIDs are administered before exposure to radiotherapy. When used in combination, it is preferable to use the appropriate chemotherapeutic agent to achieve the appropriate response, due to the complexity of signaling pathways that contribute to the regulation of COX-2 in cancer cells. For a variety of cancers, COX-2 is a marker that indicates worse prognosis and a stimulator for many cancers due to COX-2 and its extensive involvement in the pathogenesis. Therefore, the suppression of COX-2 is a very promising approach to cancer therapy when paired as an adjuvant with appropriate chemotherapeutic agents [92].

\section{Alpha-2 Agonist}

The two major alpha-2 agonist drugs most commonly used in the setting of anesthesia are clonidine and dexmedetomidine. Clonidine, a mixed alpha-1 and alpha-2 adrenoreceptor agonist with predominant alpha- 2 action, has gained popularity as an adjuvant to regional and general anesthesia in both pediatric and adult populations [93]. With regard to clonidine's sedative effects, it has been used as an adjuvant to other anesthetic agents. Dexmedetomidine is a highly selective alpha-2 adrenergic receptor agonist and is useful clinically for its sedative, analgesic, and sympatholytic effects. These effects are advantageous and include sedation with minimal respiratory depression, and reduction in the stress response, analgesia, and requirement for volatile 
anesthetics. Hence, there is less need for opioids and anesthetics. Presumably, the use of dexmedetomidine would be beneficial in surgeries. One meta-analysis reported that the use of dexmedetomidine as an adjuvant in intrathecal anesthesia demonstrated faster onset of sensory block and longer duration of stable sensory block and overall sensory block when compared to the clonidine group (see Table 1) [93].

\section{Beta Blockers}

Beta-adrenergic blockade is usually discussed in the context of cardiovascular physiology. To date, there has been minimal research investigating the use of beta-adrenergic antagonists during anesthesia or in postoperative pain management. Studies have shown that the continuous infusion of esmolol resulted in a decreased plasma propofol minimal alveolar concentration (MAC) during propofol/nitrous oxide/morphine anesthesia and reduced isoflurane MAC during anesthesia with isoflurane/ alfentanil [94]. The exact mechanism of betaadrenergic antagonist potentiation of these effects remains controversial. A reduction of hepatic blood flow has been noted following the administration of propranolol, resulting in a decrease in the metabolism of agents primarily metabolized by the hepatic system. This property results in a prolonged analgesic effect of fentanyl, which can decrease the consumption of opioids postoperatively. One study demonstrated that perioperative administration of esmolol decreased early postoperative pain intensity, opioid requirement, and the requirement for rescue analgesics and postoperative nausea and vomiting (see Table 1) [95]. Anthracycline-based chemotherapy regimens can lead to dose-dependent cardiotoxicity. Recent studies have shown a smaller pre-and post-chemotherapy reduction in left ventricular ejection fraction (LVEF) compared to controls. This therapeutic effect can be attributed to the beta-adrenergic antagonist's ability to reduce the oxidative stress and myocardial calcium overload. The optimal duration for a prophylactic beta-adrenergic antagonist intervention to exert a therapeutic effect is unclear. A study demonstrated that prophylactic use of carvedilol might attenuate or prevent the decline in
LVEF associated with the use of anthracyclines to treat cancer (see Table 1) [96]. Another study demonstrated that use of carvedilol resulted in a significant reduction in troponin levels and diastolic dysfunction [97].

\section{Dexamethasone}

Dexamethasone is a glucocorticoid steroid with anti-inflammatory properties used as a pretreatment drug in cancer patients undergoing chemotherapy. Dexamethasone carries out this function by binding to the glucocorticoid receptor to prevent allergic reactions and side effects seen with chemotherapy. One study showed that the use of dexamethasone with a semi-synthetic analog of paclitaxel reduced the sensitivity of triple-negative breast cancer cells to treat many diseases, including cancer, where it assists in managing various side effects of chemotherapy, radiotherapy, and immunotherapies. Studies have shown that dexamethasone glucocorticoid receptor activation inhibits the taxane-induced tumor cell death in breast, cervical, ovarian, and lung cancer cell lines and xenograft models [98]. The transcription of several genes is directly activated through glucocorticoid receptor activation, which encode for proteins that promote epithelial cell survival during apoptosis. Cotreatment with glucocorticoids was shown to switch the balance between several interacting signaling pathways to death in lymphoid cells but to survival in cells derived from tissue or a solid tumor. Therefore, it has been suggested that glucocorticoids should be replaced with nonsteroidal anti-emetic agents for cancer therapy-induced emesis, since they do not induce therapy resistance [99]. A meta-analysis of randomized controlled trials showed that the coadministration of dexamethasone and local anesthetics for local anesthesia prolonged the duration of sensory block/analgesia. This effect was observed more frequently in the long-acting anesthetics compared to the intermediateacting local anesthetics. Neuronal damage due to dexamethasone has not been reported, and one study demonstrated that dexamethasone attenuates the neurotoxicity associated with bupivacaine at the cellular level [100]. 
Table 1 Adjuvant therapy in chemotherapy and anesthesia

\begin{tabular}{|c|c|c|c|}
\hline $\begin{array}{l}\text { Author } \\
\text { (year) }\end{array}$ & $\begin{array}{l}\text { Groups studied and } \\
\text { intervention }\end{array}$ & Results and findings & Conclusions \\
\hline $\begin{array}{l}\text { Study 1: } \\
\text { Zhou } \\
\text { [89] }\end{array}$ & $\begin{array}{l}\text { Gastric cancer patients } \\
\text { undergoing radical gastrectomy } \\
\text { followed by adjuvant } \\
\text { chemotherapy } \\
\text { Evaluate the clinical efficiency and } \\
\text { safety of celecoxib combined } \\
\text { with chemotherapy in treatment } \\
\text { of gastric cancer }\end{array}$ & $\begin{array}{l}\text { Patients with }(+) \text { COX-2 from } \\
\text { experimental group had a } \\
\text { significantly higher } 3 \text {-year OS }\end{array}$ & $\begin{array}{l}\text { Celecoxib combined with } \\
\text { chemotherapy yields clinical } \\
\text { benefits for gastric cancer } \\
\text { patients with positive COX-2, } \\
\text { which not only enhances the OS, } \\
\text { DFS, PFS, QoL, and short-term } \\
\text { clinical efficacy, but also does not } \\
\text { increase the risk of adverse } \\
\text { events }\end{array}$ \\
\hline $\begin{array}{l}\text { Study 2: } \\
\text { Weidong } \\
\text { Mi [93] }\end{array}$ & $\begin{array}{l}\text { Seven studies that included } 354 \\
\text { subjects that were } \geq 18 \text { years of } \\
\text { age that received intrathecal } \\
\text { anesthesia or analgesia } \\
\text { Compared the characteristics of } \\
\text { clonidine vs. dexmedetomidine } \\
\text { as adjuvants to local anesthetic } \\
\text { on adults }\end{array}$ & $\begin{array}{l}\text { When dexmedetomidine was } \\
\text { applied as an adjuvant to the } \\
\text { intrathecal injection, sensory } \\
\text { block onset was substantially } \\
\text { shortened by } 40 \mathrm{~s} \text {. The duration } \\
\text { of the stable sensory block, the } \\
\text { duration of the complete sensory } \\
\text { block, and the time before } \\
\text { analgesic requirements were } \\
\text { needed were significantly } \\
\text { extended when } \\
\text { dexmedetomidine was used. No } \\
\text { significant differences were } \\
\text { detected in the motor block } \\
\text { characteristics and the time to } \\
\text { achieve peak sensory level } \\
\text { between dexmedetomidine and } \\
\text { clonidine }\end{array}$ & $\begin{array}{l}\text { Compared to clonidine, the } \\
\text { addition of dexmedetomidine as } \\
\text { an adjuvant to local anesthetics is } \\
\text { associated with earlier, prolonged } \\
\text { sensory block characteristics and } \\
\text { later need for analgesic } \\
\text { requirements }\end{array}$ \\
\hline $\begin{array}{l}\text { Study 3: } \\
\text { Cleland } \\
\text { [96] }\end{array}$ & $\begin{array}{l}\text { A double-blind study in patients } \\
\text { treated with doxorubicin, } \\
\text { comparing placebo with } \\
\text { different doses of carvedilol }\end{array}$ & $\begin{array}{l}\text { In placebo-assigned patients, LVEF } \\
\text { decreased from } 62 \pm 5 \% \text { at } \\
\text { baseline to } 58 \pm 7 \% \text { at } 6 \\
\text { months }(p=0.002) \text {, but no } \\
\text { statistically significant differences } \\
\text { were found in any of the } 3 \\
\text { carvedilol groups } \\
\text { Just one of } 116 \text { patients ( } 1 \%) \\
\text { assigned to carvedilol had an } \\
\text { LVEF }<50 \% \text { at } 6 \text { months, } \\
\text { compared to four of the } 38 \\
\text { patients assigned to placebo } \\
(11 \%)(p=0.013) \text {. In terms of } \\
\text { development of diastolic } \\
\text { dysfunction, no major variations } \\
\text { were reported between carvedilol } \\
\text { and placebo }\end{array}$ & $\begin{array}{l}\text { Carvedilol can prevent LVEF } \\
\text { deterioration in doxorubicin- } \\
\text { treated cancer patients. Within } \\
\text { the spectrum analyzed, this effect } \\
\text { may not be dose-related }\end{array}$ \\
\hline
\end{tabular}


Table 1 continued

\begin{tabular}{|c|c|c|c|}
\hline $\begin{array}{l}\text { Author } \\
\text { (year) }\end{array}$ & $\begin{array}{l}\text { Groups studied and } \\
\text { intervention }\end{array}$ & Results and findings & Conclusions \\
\hline $\begin{array}{l}\text { Study 4: } \\
\text { Edimar } \\
\text { Alcides } \\
\text { Bocchi } \\
\text { [97] }\end{array}$ & $\begin{array}{l}200 \text { patients with HER2-negative } \\
\text { breast cancer status and normal } \\
\text { LVEF were referred for ANT } \\
\left(240 \mathrm{mg} / \mathrm{m}^{2}\right) \text { before } \\
\text { completion of chemotherapy to } \\
\text { receive carvedilol or placebo }\end{array}$ & $\begin{array}{l}\text { No differences in changes of LVEF } \\
\text { or B-type natriuretic peptide } \\
\text { were noted between groups. A } \\
\text { significant difference existed } \\
\text { between groups in troponin I } \\
\text { levels over time, with lower levels } \\
\text { in the carvedilol group } \\
\text { ( } p=0.003) \text {. Additionally, a } \\
\text { lower incidence of diastolic } \\
\text { dysfunction was noted in the } \\
\text { carvedilol group ( } p=0.039) \text { A } \\
\text { nonsignificant trend toward a } \\
\text { less pronounced increase in LV } \\
\text { end-diastolic diameter during the } \\
\text { follow-up was noted in the } \\
\text { carvedilol group } \\
\text { (44.1 } \pm 3.64 \mathrm{~mm} \text { to } \\
45.2 \pm 3.2 \mathrm{~mm} \text { vs. } \\
44.9 \pm 3.6 \mathrm{~mm} \text { to } \\
46.4 \pm 4.0 \mathrm{~mm} ; p=0.057 \text { ) }\end{array}$ & $\begin{array}{l}\text { Carvedilol had no impact on the } \\
\text { incidence of early onset of LVEF } \\
\text { reduction. However, the use of } \\
\text { carvedilol resulted in a } \\
\text { significant reduction in troponin } \\
\text { levels and diastolic dysfunction }\end{array}$ \\
\hline $\begin{array}{l}\text { Study 5: } \\
\text { Van Wijk } \\
{[95]}\end{array}$ & $\begin{array}{l}\text { Consisted of } 19 \text { RCTs with a } \\
\text { total of } 936 \text { participants, } 470 \\
\text { receiving esmolol and } 466 \\
\text { receiving placebo }\end{array}$ & $\begin{array}{l}\text { Numeric pain scores at rest in the } \\
\text { immediate postoperative cycle in } \\
\text { the esmolol community were } \\
\text { decreased by } 1.16(95 \% \\
\text { confidence interval [CI]: } \\
\left.1.97-0.35, I^{2}=96.7 \%\right) \text { out of } \\
10 . \text { In the post-anesthesia } \\
\text { treatment unit, opioid intake } \\
\text { was also decreased relative to } \\
\text { placebo, mean difference of } \\
5.1 \text { mg }(95 \% \text { CI: } 7.0-3.2 \text {, } \\
\left.I^{2}=96.9 \%\right) \text { morphine IV } \\
\text { equivalents; a } 69 \% \text { decrease in } \\
\text { opioid rescue dose was observed } \\
\text { (odds ratio [OR]: } 0.31,95 \% \mathrm{CI} \text { : } \\
\left.0.16-0.80, I^{2}=0.0 \%\right) \text {. There } \\
\text { was also a } 61 \% \text { drop in } \\
\text { postoperative nausea and } \\
\text { vomiting (OR: } 0.39 \text {, CI } 95 \% \text { : } \\
\left.0.20-0.75, I^{2}=60.7 \%\right)\end{array}$ & $\begin{array}{l}\text { Perioperative esmolol as an adjunct } \\
\text { may reduce postoperative pain } \\
\text { intensity, opioid consumption, } \\
\text { and postoperative nausea } \\
\text { vomiting }\end{array}$ \\
\hline
\end{tabular}

LVEF left ventricular ejection fraction, $A N T$ anthracycline, $R C T$ randomized controlled trial, $C O X-2$ cyclooxygenase-2, $O S$ overall survival, $D F S$ disease-free survival, $P F S$ progression-free survival, $Q O L$ quality of life

\section{Oxygen}

A unique therapeutic challenge in the treatment of solid tumors is tumor hypoxia. Tumor hypoxia is a poor prognostic factor in multiple cancer types. Recently, researchers have been centered on either increasing the amount of oxygen being delivered or administering additional agents that preferentially radiosensitize or kill hypoxic cells. Hypoxia is associated with resistance to radiotherapy and standard chemotherapy, because the presence of oxygen is necessary for optimal fixation of DNA damage 
induced by the ionized radiation [101]. These hypoxic cells are much more invasive and metastatic, resistant to apoptosis, and genetically unstable [102]. Resistance to anti-cancer drugs can be explained with the example bleomycin. Bleomycin resembles radiation in that oxygen increases the cytotoxicity of this agent, resulting in DNA lesions. The addition of Fluosol-DA treatment combined with breathing high oxygen atmosphere has been shown to improve response to treatment with bleomycin, nitrosoureas, carboplatin, cyclophosphamide, melphalan, and thioTEPA in several animal tumor systems [103]. Hemoglobin-based oxygen-carrying solutions (HBOC) increase the oxygenation throughout experimental tumors under normal breathing conditions, and therefore the combination of HBOC with chemotherapeutic agents (such as carmustine, cyclophosphamide, ifosfamide, Adriamycin, TNP-470, minocycline, melphalan, and cisplatin) significantly decreases the progression of tumor growth [104-107]. Upon exposure to hypoxia, cancer cells undergo replication stress and upregulate the DNA damage and repair pathways. Many anticancer drugs kill tumor cells by causing DNA damage, which is considered the mechanism of action of these chemotherapeutic agents. HIF- $1 \alpha$ is associated with the increased chemoresistant phenotype of cancer cells, and downregulation of HIF- $1 \alpha$ can result in increased sensitivity toward etoposide treatment. One study showed that etoposide inhibited DNA strands more frequently under hypoxic conditions than under normoxic conditions due to increased levels of free radical scavenger dehydrogenase inhibitors and dehydrogenase substrates [108]. These studies show that hypoxia can induce a significant inhibitory effect on chemotherapy efficiency. Cancer resistance can be overcome by effectively interfering with hypoxia to improve the therapeutic effect.

\section{CONCLUSION}

Currently, cancer is a leading worldwide health problem. To provide optimal treatment to these patients, it is imperative that there is collaboration among anesthesiologists and surgeons. It is very clear that radiochemotherapy and medical procedures are crucial in cancerrelated therapy. Multiple challenges for anesthesia exist when faced with cancer treatment such as derangements in physiology, tumor-associated effects, and conventional chemotherapy treatment toxicities. Therefore, it is essential that a multisystemic, multidisciplinary, and patient-centered approach is utilized in order to maintain perioperative homeostasis and immune function integrity. The addition of adjuvants can help to improve patient safety and satisfaction and enhance clinical efficiency. Correctly paired anesthetic techniques and drugs can minimize the perioperative inflammatory and immune changes, which can potentially lead to enhanced outcomes for future cancer patients. Further research into the best techniques for practice is needed and will help improve the acute and long-term effects seen with cancer treatment in clinical practice.

\section{ACKNOWLEDGEMENTS}

Funding. No funding or sponsorship was received for this study or publication of this article.

Authorship. All named authors meet the International Committee of Medical Journal Editors (ICMJE) criteria for authorship for this article, take responsibility for the integrity of the work as a whole, and have given their approval for this version to be published.

Disclosures. Jeremy Watson, Michael Ninh, Scott Ashford, Elyse Cornett, Alan Kaye, Ivan Urits, and Omar Viswanath have nothing to disclose.

Compliance with Ethics Guidelines. This article is based on previously conducted studies and does not contain any new studies with human participants or animals performed by any of the authors. 
Open Access. This article is licensed under a Creative Commons Attribution-NonCommercial 4.0 International License, which permits any non-commercial use, sharing, adaptation, distribution and reproduction in any medium or format, as long as you give appropriate credit to the original author(s) and the source, provide a link to the Creative Commons licence, and indicate if changes were made. The images or other third party material in this article are included in the article's Creative Commons licence, unless indicated otherwise in a credit line to the material. If material is not included in the article's Creative Commons licence and your intended use is not permitted by statutory regulation or exceeds the permitted use, you will need to obtain permission directly from the copyright holder. To view a copy of this licence, visit http://creativecommons.org/licenses/by$\mathrm{nc} / 4.0 /$.

\section{REFERENCES}

1. Fitzmaurice $\mathrm{C}$, Akinyemiju TF, Al Lami FH, Alam T, Alizadeh-Navaei R, Allen C, et al. Global, regional, and national cancer incidence, mortality, years of life lost, years lived with disability, and disabilityadjusted life-years for 29 cancer groups, 1990 to 2016 a systematic analysis for the global burden of disease study global burden o. JAMA Oncol. 2018;4(11):1553-68.

2. Melamed R, Bar-Yosef S, Shakhar G, Shakhar K, BenEliyahu S. Suppression of natural killer cell activity and promotion of tumor metastasis by Ketamine, Thiopental, and Halothane, but not by Propofol: mediating mechanisms and prophylactic measures. Anesth Analg. 2003;97(5):1331-9.

3. Kim R. Effects of surgery and anesthetic choice on immunosuppression and cancer recurrence. J Transl Med. 2018;16(1):1-13.

4. Alan David Kaye NP, FRB, BH, NV, GK, RDU. Effect of opiates, anesthetic techniques, and other perioperative factors on surgical cancer patients. PubMed. 2014;14(2):216-28.

5. Tavare AN, Perry NJS, Benzonana LL, Takata M, Ma D. Cancer recurrence after surgery: direct and indirect effects of anesthetic agents. Int J Cancer. 2012;130:1237-50 (John Wiley \& Sons, Ltd).
6. Huang H, Benzonana LL, Zhao H, Watts HR, Perry NJ, Bevan C, et al. Prostate cancer cell malignancy via modulation of HIF-1 $\alpha$ pathway with isoflurane and propofol alone and in combination. Br J Cancer. 2014;111(7):1338-49.

7. Loop T, Dovi-Akue D, Frick M, Roesslein M, Egger L, Humar M, et al. Volatile anesthetics induce caspasedependent, mitochondria-mediated apoptosis in human $\mathrm{T}$ lymphocytes in vitro. Anesthesiology. 2005;102(6):1147-57.

8. Benzonana LL, Perry NJS, Watts HR, Yang B, Perry IA, Coombes C, et al. Isoflurane, a commonly used volatile anesthetic, enhances renal cancer growth and malignant potential via the hypoxia-inducible factor cellular signaling pathway in vitro. Anesthesiology. 2013;119(3):593-605.

9. Ding S, Huang H, Xu Y, Shen L, Zhong C, Zheng S. Neuroepithelial cell transforming gene 1 acts as an oncogene and is mediated by miR-22 in human non-small-cell lung cancer. Bio Med Res Int. 2020. https://doi.org/10.1155/2020/1648419.

10. Jiang S, Liu Y, Huang L, Zhang F, Kang R. Effects of propofol on cancer development and chemotherapy: potential mechanisms. Eur J Pharmacol. 2018;831:46-51 (Elsevier B.V.).

11. Yang N, Liang Y, Yang P, Ji F. Propofol suppresses LPS-induced nuclear accumulation of HIF-1 $\alpha$ and tumor aggressiveness in non-small cell lung cancer. Oncol Rep. 2017;37(5):2611-9.

12. Yu B, Gao W, Zhou H, Miao X, Chang Y, Wang L, et al. Propofol induces apoptosis of breast cancer cells by downregulation of miR-24 signal pathway. Cancer Biomark. 2018;21(3):513-9.

13. Yang C, Gao J, Yan N, Wu B, Ren Y, Li H, et al. Propofol inhibits the growth and survival of gastric cancer cells in vitro through the upregulation of ING3. Oncol Rep. 2017;37(1):587-93.

14. Reed SM, Quelle DE. P53 acetylation: regulation and consequences. Cancers. 2014;7:30-69 (MDPI AG).

15. Lu M, Chen F, Wang Q, Wang K, Pan Q, Zhang X. Downregulation of inhibitor of growth 3 is correlated with tumorigenesis and progression of hepatocellular carcinoma. Oncol Lett. 2012;4(1):47-52.

16. Gunduz M, Ouchida M, Fukushima K, Ito S, Jitsumori $Y$, Nakashima $T$, et al. Allelic loss and reduced expression of the ING3, a candidate tumor suppressor gene at 7q31, in human head and neck cancers. Oncogene. 2002;21(28):4462-70.

17. Henriksson R, Grankvist K. Interactions between anticancer drugs and other clinically used pharmaceuticals: a review. Acta Oncol. 1989;28(4):451-62. 
18. Bruce DL. Anesthetic-induced increase in murine mortality from cyclophosphamide. Cancer. 1973;31(2):361-3.

19. Kennedy KA, Hait WN, Lazo JS. Chemical modulation of bleomycin induced toxicity. Int J Radiat Oncol Biol Phys. 1986;12(8):1367-70.

20. Nelson-Veniard M, Thambo JB. Chemotherapy-induced cardiotoxicity: incidence, diagnosis and prevention. Bull Cancer. 2015;102:622-6 (John Libbey Eurotext).

21. Braun S, Gaza N, Werdehausen R, Hermanns H, Bauer I, Durieux ME, et al. Ketamine induces apoptosis via the mitochondrial pathway in human lymphocytes and neuronal cells. $\mathrm{Br} \mathrm{J}$ Anaesth. 2010;105(3):347-54.

22. He H, Chen J, Xie WP, Cao S, Hu HY, Yang LQ, et al. Ketamine used as an acesodyne in human breast cancer therapy causes an undesirable side effect, upregulating anti-apoptosis protein Bcl-2 expression. Genet Mol Res. 2013;12(2):1907-15.

23. Ohta N, Ohashi Y, Fujino Y. Ketamine inhibits maturation of bone marrow-derived dendritic cells and priming of the Th1-type immune response. Anesth Analg. 2009;109(3):793-800.

24. Loop T, Liu Z, Humar M, Hoetzel A, Benzing A, Pahl HL, et al. Thiopental inhibits the activation of nuclear factor $\mathrm{\kappa B}$. Anesthesiology. 2002;96(5): 1202-13.

25. Inada T, Kubo K, Shingu K. Possible link between cyclooxygenase-inhibiting and antitumor properties of propofol. J Anesth. 2011;25:569-75.

26. Kushida A, Inada T, Shingu K. Enhancement of antitumor immunity after propofol treatment in mice. Immunopharmacol Immunotoxicol. 2007;29(3-4):477-86.

27. Liu TC. Influence of propofol, isoflurane and enflurance on levels of serum interleukin- 8 and interleukin-10 in cancer patients. Asian Pac J Cancer Prev. 2014;15(16):6703-7.

28. Inada T, Yamanouchi Y, Jomura S, Sakamoto S, Takahashi M, Kambara T, et al. Effect of propofol and isoflurane anaesthesia on the immune response to surgery. Anaesthesia. 2004;59(10):954-9.

29. Connolly C, Buggy DJ. Opioids and tumour metastasis: Does the choice of the anesthetic-analgesic technique influence outcome after cancer surgery? Curr Opin Anaesthesiol. 2016;29:468-74 (Lippincott Williams and Wilkins).

30. Mathew B, Lennon FE, Siegler J, Mirzapoiazova T, Mambetsariev N, Sammani S, et al. The novel role of the mu opioid receptor in lung cancer progression: a laboratory investigation. Anesth Analg. 2011;112(3):558-67.

31. Janku F, Johnson LK, Karp DD, Atkins JT, Singleton PA, Moss J. Treatment with methylnaltrexone is associated with increased survival in patients with advanced cancer. Ann Oncol. 2016;27(11):2032-8.

32. Doornebal CW, Vrijland K, Hau CS, Coffelt SB, Ciampricotti M, Jonkers J, et al. Morphine does not facilitate breast cancer progression in two preclinical mouse models for human invasive lobular and HER2+ breast cancer. Pain. 2015;156(8):1424-32.

33. Afsharimani B, Baran J, Watanabe S, Lindner D, Cabot PJ, Parat MO. Morphine and breast tumor metastasis: the role of matrix-degrading enzymes. Clin Exp Metastasis. 2014;31(2):149-58.

34. Koodie L, Yuan H, Pumper JA, Yu H, Charboneau R, Ramkrishnan S, et al. Morphine inhibits migration of tumor-infiltrating leukocytes and suppresses angiogenesis associated with tumor growth in mice. Am J Pathol. 2014;184(4):1073-84.

35. Zhao H, Iwasaki M, Yang J, Savage S, Ma D. Hypoxia-inducible factor-1: A possible link between inhalational anesthetics and tumor progression? Acta Anaesthesiol Taiwan. 2014;52:70-6 (Elsevier Taiwan LLC).

36. Liang H, Yang CX, Zhang B, Wang HB, Liu HZ, Lai $\mathrm{XH}$, et al. Sevoflurane suppresses hypoxia-induced growth and metastasis of lung cancer cells via inhibiting hypoxia-inducible factor- $1 \alpha$. J Anesth. 2015;29(6):821-30.

37. Yang Y, Hu R, Yan J, Chen Z, Lu Y, Jiang J, et al. Sevoflurane inhibits the malignant potential of head and neck squamous cell carcinoma via activating the hypoxia-inducible factor-1a signaling pathway in vitro. Int J Mol Med. 2018;41(2): 995-1002.

38. Luo X, Zhao H, Hennah L, Ning J, Liu J, Tu H, et al. Impact of is of lurane on malignant capability of ovarian cancer in vitro. Br J Anaesth. 2015;114(5): 831-9.

39. Pirbudak Cocelli L, Ugur MG, Karadasli H. Comparison of effects of low-flow sevoflurane and desflurane anesthesia on neutrophil and T-cell populations. Curr Ther Res - Clin Exp. 2012;73(1-2):41-51.

40. Allan N, Siller C, Breen A. Anaesthetic implications of chemotherapy. Contin Educ Anaesth Crit Care Pain. 2012;12(2):52-6.

41. Sun Z, Adam MA, Kim J, Nussbaum DP, Benrashid E, Mantyh CR, et al. Determining the optimal timing 
for initiation of adjuvant chemotherapy after resection for stage II and III colon cancer. Dis Colon Rectum. 2016;59:87-93 (Lippincott Williams and Wilkins).

42. Visser E, Leeftink AG, van Rossum PSN, Siesling S, van Hillegersberg R, Ruurda JP. Waiting time from diagnosis to treatment has no impact on survival in patients with esophageal cancer. Ann Surg Oncol. 2016;23(8):2679-89.

43. Liu Y, Zhang KC, Huang XH, Xi HQ, Gao YH, Liang $W Q$, et al. Timing of surgery after neoadjuvant chemotherapy for gastric cancer: impact on outcomes. World J Gastroenterol. 2018;24(2):257-65.

44. Petrelli F, Zaniboni A, Ghidini A, Ghidini M, Turati L, Pizzo C, et al. Timing of adjuvant chemotherapy and survival in colorectal, gastric, and pancreatic cancer. A systematic review and meta-analysis. Cancers. 2019;11(4):550.

45. Bleicher RJ. Timing and delays in breast cancer evaluation and treatment. Ann Surg Oncol. 2018;25(10):2829-38.

46. Suleman K, Almalik O, Haque E, Mushtaq A, Badran A, Alsayed A, et al. Does the timing of surgery after neoadjuvant therapy in breast cancer patients affect the outcome? Oncology. 2020;98(3):168-73.

47. Chavez-MacGregor M, Clarke CA, Lichtensztajn DY, Giordano SH. Delayed initiation of adjuvant chemotherapy among patients with breast cancer. JAMA Oncol. 2016;2(3):322-9.

48. Zhang LIN, Zuo M, Ma X, Dong Y. Effects of neoadjuvant chemotherapy on minimum alveolar concentration values of sevoflurane and desflurane in patients with hepatocellular carcinoma complicated with jaundice. Oncol Lett. 2018. https://doi. org/10.3892/ol.2018.8621.

49. Du W, Li C, Wang H, Zhao A, Shen J, Yong F, et al. Effect of neoadjuvant chemotherapy on sevoflurane MAC-BAR value of patients undergoing radical stomach carcinoma surgery. Int J Clin Exp Med. 2015;8(4):5649-57.

50. Xu Y, Jiang W, Xie S, Xue F, Zhu X. The role of inhaled anesthetics in tumorigenesis and tumor immunity. Cancer Manage Res. 2020;12:1601.

51. Rudnick S, Stevenson GW, Hall SC, Espinoza-Delgado I, Stevenson HC, Longo DL. Halothane potentiates the antitumor activity of gamma-interferon and mimics calmodulin-blocking agents. Anesthesiology. 1991;74(1):115-9.

52. Ciechanowicz S, Zhao H, Chen Q, Cui J, Mi E, Ma D, et al. Differential effects of sevoflurane on the metastatic potential and chemosensitivity of non- small-cell lung adenocarcinoma and renal cell carcinoma in vitro. Br J Anaesth. 2018;120(2):368-75.

53. Ecimovic P, Mchugh B, Murray D, Doran P, Buggy DJ. Effects of sevoflurane on breast cancer cell function in vitro. Anticancer Res. 2013;33(10): $4255-60$.

54. Tan Z, Peng A, Xu J, Ouyang M. Propofol enhances BCR-ABL TKIs' inhibitory effects in chronic myeloid leukemia through Akt/mTOR suppression. BMC Anesthesiol. 2017. https://doi.org/10.1186/s12871017-0423-2.

55. Li H, Lu Y, Pang Y, Li M, Cheng X, Chen J. Propofol enhances the cisplatin-induced apoptosis on cervical cancer cells via EGFR/JAK2/STAT3 pathway. Biomed Pharmacother. 2017;86:324-33.

56. Wang P, Chen J, Mu LH, Du QH, Niu XH, Zhang MY. Propofol inhibits invasion and enhances paclitaxelinduced apoptosis in ovarian cancer cells through the suppression of the transcription factor slug. Eur Rev Med Pharmacol Sci. 2013;17(13): 1722-9.

57. Du QH, Xu YB, Zhang MY, Yun P, He CY. Propofol induces apoptosis and increases gemcitabine sensitivity in pancreatic cancer cells in vitro by inhibition of nuclear factor- $\kappa \mathrm{B}$ activity. World J Gastroenterol. 2013;19(33):5485-92. https://doi. org/10.3748/wjg.v19.i33.5485

58. Zhang Y, Wang X, Wang Q, Ge H, Tao L. Propofol depresses cisplatin cytotoxicity via the inhibition of gap junctions. Mol Med Rep. 2016;4715-20. https:// doi.org/10.3892/mmr.2016.5119.

59. Zhao S, Shao L, Wang Y, Meng Q, Yu J. Ketamine exhibits anti-gastric cancer activity via induction of apoptosis and attenuation of PI3K/Akt/mTOR. Arch Med Sci. 2019;16(5):1140-9. https://doi.org/10. 5114/aoms.2019.85146.eCollection2020.

60. Malsy M, Gebhardt K, Gruber M, Wiese C, Graf B, Bundscherer A. Effects of ketamine, s-ketamine, and MK 801 on proliferation, apoptosis, and necrosis in pancreatic cancer cells. BMC Anesthesiol. 2015;15: 111.

61. Zhou X, Zhang P, Luo W, Zhang L, Hu R, Sun Y, et al. Ketamine induces apoptosis in lung adenocarcinoma cells by regulating the expression of CD69. Cancer Med. 2018;7(3):788-95. https://doi. org/10.1002/cam4.1288

62. Garmon EH, Dulebohn SC. Topical, local, and regional anesthesia and anesthetics. Statpearls. Treasure Island (FL): StatPearls Publishing. 2021. https://www.ncbi.nlm.nih.gov/books/NBK430894/ 
63. Yang X, Zhao L, Li M, Yan L, Zhang S, Mi Z, et al. Lidocaine enhances the effects of chemotherapeutic drugs against bladder cancer. Sci Rep. 2018;8:598.

64. Li K, Yang J, Han X. Lidocaine sensitizes the cytotoxicity of cisplatin in breast cancer cells via upregulation of RAR $\beta 2$ and RASSF1A demethylation. Int J Mol Sci. 2014;15(12):23519-36. https://doi. org/10.3390/ijms151223519

65. Dan J, Gong X, Li D, Zhu G, Wang L, Li F. Inhibition of gastric cancer by local anesthetic bupivacaine through multiple mechanisms independent of sodium channel blockade. Biomed Pharmacother. 2018;103:823-8. https://doi.org/10.1016/j.biopha. 2018.04.106.

66. Zheng Q, Peng X, Zhang Y. Cytotoxicity of amidelinked local anesthetics on melanoma cells via inhibition of Ras and RhoA signaling independent of sodium channel blockade. BMC Anesthesiol. 2020;20:43.

67. Yang Q, Zhang Z, Xu H, Ma C. Lidocaine alleviates cytotoxicity-resistance in lung cancer A549/DDP cells via down-regulation of miR-21. Mol Cell Biochem. 2019;456(1-2):63-72. https://doi.org/10. 1007/s11010-018-3490-x.

68. Zhang X, Pang W, Liu H, Wang J. Lidocine potentiates the cytotoxicity of 5-fluorouracil to choriocarcinoma cells by downregulating $\mathrm{ABC}$ transport proteins expression. J Cell Biochem. 2019;120(10). https://doi.org/10.1002/jcb.28913.

69. Emelife PI, Eng MR, Menard BL, Myers AS, Cornett EM, Urman RD, et al. Adjunct medications for peripheral and neuraxial anesthesia. Best Pract Res Clin Anaesthesiol. 2018;32(2):83-99.

70. Busch-Dienstfertig M, Stein C. Opioid receptors and opioid peptide-producing leukocytes in inflammatory pain-basic and therapeutic aspects. Brain Behav Immun. 2010;24(5):683-94. https://doi.org/ 10.1016/j.bbi.2009.10.013.

71. Zylla D, Steele G, Gupta P. A systematic review of the impact of pain on overall survival in patients with cancer. Support Care Cancer. 2017;25(5): 1687-98.

72. He B, Tong X, Wang L, Wang Q, Ye H, Liu B, et al. Tramadol and flurbiprofen depress the cytotoxicity of cisplatin via their effects on gap junctions. Clin Cancer Res. 2009;15(8):5803-10.

73. Sacerdote P, Manfredi B, Mantegazza P, Panerai AE. Antinociceptive and immunosuppressive effects of opiate drugs: a structure-related activity study. Br J Pharmacol. 1997;121(4):834-40.
74. Sacerdote P, Bianchi M, Gaspani L, Manfredi B, Maucione A, Terno G, et al. The effects of tramadol and morphine on immune responses and pain after surgery in cancer patients. Anesth Analg. 2000;90(6):1411-4.

75. Markovic SN, Knight PR, Murasko DM. Inhibition of interferon stimulation of natural killer cell activity in mice anesthetized with halothane or isoflurane. Anesthesiology. 1993;78(4):700-6.

76. Sacerdote P, Limiroli E, Gaspani L. Experimental evidence for immunomodulatory effects of opioids. $2013 . \quad$ https://www.ncbi.nlm.nih.gov/books/ NBK6402/, Austin (TX): Landes Bioscience; 2000-2013.

77. McCarthy L, Wetzel M, Sliker JK, Eisenstein TK, Rogers TJ. Opioids, opioid receptors, and the immune response. Drug Alcohol Depend. 2001;62: $111-23$

78. Sacerdote P. Opioid-induced immunosuppression. Curr Opin Support Palliat Care. 2008;2:14-8.

79. Sasu-Tenkoramaa J, PharmD, Fudin J, PharmD, DAIPM, FCCP, et al. Drug interactions in cancer patients requiring concomitant chemotherapy and analgesics. Practical pain management. [cited 2021 Mar 9]. Available from: https://www. practicalpainmanagement.com/pain/cancer/ chemotherapy-neuropathy/drug-interactionscancer-patients-requiring-concomitant

80. Chamaraux-Tran TN, Mathelin C, Aprahamian M, Joshi GP, Tomasetto C, Diemunsch P, et al. Antitumor effects of lidocaine on human breast cancer cells: An in vitro and in vivo experimental trial. Anticancer Res. 2018;38(1):95-105. https://doi.org/ 10.21873/anticanres.12196.

81. Freeman J, Crowley PD, Foley AG, Gallagher HC, Iwasaki M, Ma D, et al. Effect of perioperative lidocaine, propofol and steroids on pulmonary metastasis in a murine model of breast cancer surgery. Cancers. 2019;11(5):613. https://doi.org/10.3390/ cancers 11050613.

82. Lirk P, Berger R, Hollmann MW, Fiegl H. Lidocaine time- and dose-dependently demethylates deoxyribonucleic acid in breast cancer cell lines in vitro. $\mathrm{Br}$ J Anaesth. 2012;109(2):200-7. https://doi.org/10. 1093/bja/aes128.

83. Freeman J, Crowley PD, Foley AG, Gallagher HC, Iwasaki M, Ma D, et al. Effect of perioperative lidocaine and cisplatin on metastasis in a murine model of breast cancer surgery. Cancers 2019;11(5):613. https://doi.org/10.3390/cancers11050613.

84. Xing W, Chen DT, Pan JH, Chen YH, Yan Y, Li Q, et al. Lidocaine induces apoptosis and suppresses 
tumor growth in human hepatocellular carcinoma cells in vitro and in a xenograft model in vivo. Anesthesiology. 2017;126(5):868-81. https://doi. org/10.1097/ALN.0000000000001528.

85. Esbona K, Inman D, Saha S, Jeffery J, Schedin P, Wilke L, Keely P. COX-2 modulates mammary tumor progression in response to collagen density. Breast Cancer Res. 2016;18:35.

86. Mizutani Y, Nakanishi H, Li YN, Sato N, Kawauchi A, Miki T. Enhanced sensitivity of bladder cancer cells to cisplatin mediated cytotoxicity and apoptosis in vitro and in vivo by the selective cyclooxygenase-2 inhibitor JTE-522. J Urol. 2004;172(4 Pt 1):1474-9. https://doi.org/10.1097/ 01.ju.0000131945.74377.

87. Awara WM, El-Sisi AE, El-Sayad ME, Goda AE. The potential role of cyclooxygenase- 2 inhibitors in the treatment of experimentally-induced mammary tumour: Does celecoxib enhance the anti-tumour activity of doxorubicin? Pharmacol Res. 2004;50(5): 487-98. https://doi.org/10.1016/j.phrs.2004.04. 002.

88. Sung MW, Lee DY, Park SW, Oh SM, Choi JJ, Shin ES, et al. Celecoxib enhances the inhibitory effect of 5-FU on human squamous cell carcinoma proliferation by ROS production. Laryngoscope. 2017;127(4):E117-23. https://doi.org/10.1002/lary. 26309.

89. Guo Q, Liu X, Lu L, Yuan H, Wang Y, Chen Z, et al. Comprehensive evaluation of clinical efficacy and safety of celecoxib combined with chemotherapy in management of gastric cancer. Med US. 2017;96(51):e8857. https://doi.org/10.1097/MD. 0000000000008857.

90. Behrenbruch C, Shembrey C, Paquet-Fifield S, Mølck C, Cho HJ, Michael M, et al. Surgical stress response and promotion of metastasis in colorectal cancer: a complex and heterogeneous process. Clin Exp Metastasis. 2018;35(4):333-45. https://doi.org/ 10.1007/s10585-018-9873-2.

91. Shaashua L, Shabat-Simon M, Haldar R, Matzner P, Zmora O, Shabtai M, et al. Perioperative COX-2 and $\beta$-adrenergic blockade improves metastatic biomarkers in breast cancer patients in a phase-II randomized trial. Clin Cancer Res. 2017. https:// doi.org/10.1158/1078-0432.CCR-17-0152.

92. Hashemi Goradel N, Najafi M, Salehi E, Farhood B, Mortezaee K. Cyclooxygenase-2 in cancer: a review. J Cell Physiol. 2019;234(5):5683-99. https://doi. org/10.1002/jcp.27411.

93. Zhang C, Li C, Pirrone M, Sun L, Mi W. Comparison of dexmedetomidine and clonidine as adjuvants to local anesthetics for intrathecal anesthesia: a meta- analysis of randomized controlled trials. J Clin Pharmacol. 2016;56(7):827-34. https://doi.org/10. 1002/jcph.666.

94. Johansen JW, Flaishon R, Sebel PS. Esmolol reduces anesthetic requirement for skin incision during propofol/nitrous oxide/morphine anesthesia. Anesthesiology. 1997;86(2):364-71. https://doi.org/10. 1097/00000542-199702000-00011.

95. Watts R, Thiruvenkatarajan V, Calvert M, Newcombe G, Van Wijk RM. The effect of perioperative esmolol on early postoperative pain: a systematic review and meta-analysis. J Anaesthesiol Clin Pharmacol. 2017;33(1):28-39. https://doi.org/10. 4103/0970-9185.202182.

96. Abuosa AM, Elshiekh AH, Qureshi K, Abrar MB, Kholeif MA, Kinsara AJ, et al. Prophylactic use of carvedilol to prevent ventricular dysfunction in patients with cancer treated with doxorubicin. Indian Heart J. 2018;70(Suppl 3):S96-100. https:// doi.org/10.1016/j.ihj.2018.06.011.

97. Avila MS, Ayub-Ferreira SM, de Barros Wanderley MR, das Dores Cruz F, Gonçalves Brandão SM, Rigaud VOC, et al. Carvedilol for prevention of chemotherapy-related cardiotoxicity: the CECCY trial. J Am Coll Cardiol. 2018;71(20):2281-90.

98. Herr I, Ucur E, Herzer K, Okouoyo S, Ridder R, Krammer $\mathrm{PH}$, et al. Glucocorticoid cotreatment induces apoptosis resistance toward cancer therapy in carcinomas. Cancer Res. 2003;63(12):3112-20.

99. Zhang C, Wenger T, Mattern J, Ilea S, Frey C, Gutwein $\mathrm{P}$, et al. Clinical and mechanistic aspects of glucocorticoid-induced chemotherapy resistance in the majority of solid tumors. Cancer Biol Ther. 2007;6(2):278-87. https://doi.org/10.4161/cbt.6.2. 3652 .

100. Ma R, Wang X, Lu C, Li C, Cheng Y, Ding G, et al. Dexamethasone attenuated bupivacaine-induced neuron injury in vitro through a threonine-serine protein kinase B-dependent mechanism. Neuroscience. 2010;167(2):329-42. https://doi.org/10. 1016/j.neuroscience.2009.12.049.

101. Baig M, Baig M. Oxygen effect and reoxygenation. Pract Radiother Chemother Plann. 2018. https:// radiologykey.com/oxygen-effect-andreoxygenation/.

102. Melillo G. Targeting hypoxia cell signaling for cancer therapy. Cancer Metastasis Rev. 2007;26(2): 341-52. https://doi.org/10.1007/s10555-007-9059$\mathrm{x}$.

103. Yu M, Dai M, Liu Q, Xiu R. Oxygen carriers and cancer chemo- and radiotherapy sensitization: bench to bedside and back. Cancer Treat Rev. 
2007;33(8):757-61. https://doi.org/10.1016/j.ctrv. 2007.08.002.

104. Teicher BA, Herman TS, Hopkins RE, Menon K. Effect of oxygen level on the enhancement of tumor response to radiation by perfluorochemical emulsions or a bovine hemoglobin preparation. Int J Radiat Oncol Biol Phys. 1991;21(4):969-74. https://doi.org/10.1016/0360-3016(91)90737-o.

105. Teicher BA, Holden SA, Ara G, Herman TS, Hopkins RE, Menon K. Effect of a bovine hemoglobin preparation (sbhs) on the response of two murine solid tumors to radiation therapy or chemotherapeutic alkylating agents. Biomater Artif Cells Immobiliz Biotechnol. 1992;20(2-4):657-60. https://doi.org/10.3109/10731199209119697.
106. Teicher BA, Dupuis NP, Emi Y, Ikebe M, Kakeji Y, Menon K. Increased efficacy of chemo- and radiotherapy by a hemoglobin solution in the 9L gliosarcoma. In Vivo. 1995;9(1):11-8.

107. Teicher BA, Holden SA, Menon K, Hopkins RE, Gawryl MS. Effect of hemoglobin solution on the response of intracranial and subcutaneous 9L tumors to antitumor alkylating agents. Cancer Chemother Pharmacol. 1993;33(1):57-62. https:// doi.org/10.1007/BF00686024.

108. Denny WA. The role of hypoxia-activated prodrugs in cancer therapy. Lancet Oncol. 2000;1(1):25-9. https://doi.org/10.1016/S1470-2045(00)00006-1. 